\title{
LODE MINING IN THE FAIRBANKS DISTRICT, ALASKA
}

\section{By}

John A. Davis, Superintendent, Alaska Experiment Station, U. S. Bureau of Mines

\section{INTRODUCTION}

The Fairbanks district comprises an area of approximately 500 square miles in the vicinity of the town of Fairbanks which is situated on a branch of the Tanana River at Lat. $64^{\circ} 51^{\prime} \mathrm{N}$, and Long. $147^{\circ} 53^{\prime} \mathrm{W}$. A though there was a determined effort as early as 1905 to find the gold bearing quartz veins which were believed to exist as the source of the extensive placer deposits of the district, it was not until 1908 that discoveries of any importance were made. From that time unti 1915 lode mining had a rapid growth and attained a production valued at $\$ 350,000$ per year in spite of the difficulties caused by climate, by the large amount of overburden (most of which is perpetually frozen and makes the uncovering of solid rock an arduous task), by costly and inadequate transportation on river boats able to operate but four or five months during the summer, and by lack of fuel due to the rapid exhaustion of standing timber in the more favorable districts. Beginning with 3916 the steadily mounting cost of supplies caused by war conditions was added to these other difficulties. Prospecting eventually stopped; many of the mines were forced to suspend operations and the production of gold from lode mining dropped to $\$ 20,000$ per year. In 1921 , however, the Alaska (Government) Railroad was completed from Tidewater at Seward to its northern terminus at Fairbanks except for a bridge now under construction across the Tanana River, and the better shipping factitities thus afforded (despite the transfer across the Tanana) not oniy for supplies from the States but also for cheap fuel from the coal mines in the Nenana field, have caused a revtval of lode mining which is steadily gaining headway. In view of the renewed interest thus aroused it has been deened advisable to compile and publish at this time the information available on the subject of lode mining in the Fairbanks district,

ORAINAGE AND TOPOGRAPHY

The Tanana River, one of the principal steams in interior Alaska, flows west along the southern edge of the district and joins the Yukon about 225 miles below Fairbanks. The rivers next in importance within the district are the chatanika near the northern edge and 
Goldstream near the center, both flowing west into Tolovana River, which empties into the Tanana 80 miles above its junction with the Yukon. The eastern portion of the district is drained by tributaries of Chena River which flows through the town of Fairbanks and joins the Tanana 11 miles below. South of Fairbanks the broad, flat Tanana Valley extends for 25 to 40 miles until it reaches the northern foothilis of the Alaska Range. North of the town the surface rises to an upland or plateau which is intimately dissected by the alluvium-filled valleys of the larger streams and their tributarles whose walls usually rise by gentle slopes to the rounded crests of the hills, 1500 to 2000 feet higher than the level of the Tanana Valley.

\section{GENERAL GEOLOGY}

Throughout the Fairbanks district the greater portion of the bedrock is formed by a variety of metamorphic rocks which have been grouped together geologically and named Birch creek schist. In addition to various types of schists this group also includes quartzites, crystalline limestones, altered calcareous rocks, and some granitic gneiss. The rocks are closely folded, and faults are numerous. No fossils have as yet been found, hence the age has not definitely been determined, but judging from structural relations it is supposed to be wholly or in large part Cambrian.

Several varieties of intrusive rocks belonging chiefly to the granite and diorite groups are associated with the schist, and are in all 11kelihood not only the source of the mineralization of the district but also are the cause of the shattering of the schist which afforded channels for the circulation of mineral-bearing solutions.

\section{ACKNOWLEDGMENTS}

The writer wishes to express his appreciation of the cooperation and assistance in the preparation of this report he has received from mine owners and prospectors in the Fairbanks district, and to acknowledge his indebtedness to the several authors of the bulletins of the United States Geological Survey 1isted below a; especially since it has been impossible to give credit in individual instances for information obtained from these published reports which have been freely drawn upon for data of early lode mining activity.

a Mineral Resources of Alaska, 1909, Alfred H. Brooks and others, Bul1. U.S. Geol. Survey 442, Washington, 1910. 
Mineral Resources of Alaska, 1970, Alfred H. Brooks and others, Bull. U.S. Geol. Survey 480, Washington, 1911.

Mineral Resources of Alaska, 1911, A1fred H. Brooks and others, Bul1. U. S. Geol. Survey 520, Washington, 1912.

Geologic Reconnaissance of the Fairbanks Quadrangle, Alaska, L.M. Prindle, F. J. Katz, and P. S. Smith, Bu11. U.S. Geol. Survey, 525, Washington, 1913.

Mineral Resources of Alaska, 1912, Alfred H. Brooks and others, Bu11. U.S, Geol. Survey 542, Washington, 1913.

Mineral Resources of Alaska, 1913, Alfred H. Brooks and others, Bu11. U.S. Geol. Survey 592 , Washington, 1914.

Mineral Resources of Alaska, 1914, Alfred H. Brooks and others, Bu11. U.S. Geol. Survey 622, Washington, 1915.

Mineral Resources of A1aska, 1915, Alfred H. Brooks and others, Bu77. U.S. Geol. Survey 642, Washington, 1916.

Mineral Resources of Alaska, 1916, Alfred H. Brooks and others, Bu\}1. U.S. Geol. Survey 662, Washington, 1918.

Antimony Deposits of Alaska, Alfred H. Brooks, Bu11. U.S. Geo1. Survey 649, Washington, 1916. Mineral Resources of Alaska, 1917, G. C. Martin and others, Bul1. U.S. Geol. Survey, 692, Washington, 1919.

Mineral Resources of Alaska, 1918, G. C. Martin and others, Bull. U.S. Geo1. Survey, 712, Washington, 1919.

Mineral Resources of Alaska, 1979, Alfred H. Brooks and others, Bull, U. S. Geol. Survey 714, Washington, 1921.

Mineral Resources of Alaska, 1920, Aifred H. Brooks and others, Bu11. U,S. Geol. Survey 722, Washington, 1922.

Mineral Resources of Alaska, 1921, Alfred H. Brooks and others, Bu11. U.S. Geol. Survey 739, Washington, 1922.

\section{DESCRIPTION OF GOLD MINES AND PROSPECTS}

There are two princlpal areas in the Fafrbanks district where gold 1ode mining has been particularly active, the first centering around Pedro Dome which lies about 18 miles northeast of Fairbanks, the second around Ester Dome, which lies 9 or 10 miles west of the town. For convenience the descriptions of the various mines will be grouped according to the creeks in whose watershed the mines are located. Near Pedro Dome these include: Fairbanks Creek, which is one of the headwaters of the Chena River; Cleary, Littie Eldorado, Dome and Vault Creeks, which are tributaries of Chatanika River; and Pedro Creek, which is one of the main forks of Goidstream. In the neighborhood of Ester Dome, the mines are found chiefly in the watersheds of St. Patrick and Ester Creeks. These are headwaters of Cripple Creek which Joins chena River a few miles below Fairbanks.

\section{Fairbanks creek}

Hiyu Group

The Hiyu group consists of ten claims, including the Helen S., Teddy R., Hiyu and Nars, sttuated on the ridge between Too Much Gold and Moose Creeks, both of which are short tributaries of Fairbanks creek. The property is two mlles northwest of Meehan, the nearest 
postoffice, and twenty five miles northeast of Fairbanks. The most accessible railroad station is Gilmore on the Chatanika (narrow gage) branch of the Alaska Railroad. It is thirteen miles by wagon road from the property. The owners and operators of the mine are Clarence M. Crites and Henry Feldman.

The ore is free-milling gold-bearing quartz ranging in value from $\$ 25$ to $\$ 35$ per ton. The associated minerals are chiefly antimony sulfide (stibnite) although sulfides of lead, iron and zinc occur sparingly. The stibnite often occurs in lenses or kidneys but the amount of sulfides rarely exceeds five percent of the total vein material. In the surficial portions the ore is oxidized and frequently stained to a greenish color due to antimony oxide. No distinct ore shoots have been observed, and if secondary enrichment has taken place it is not a prominent characteristic of the deposit. Two distinct periods of mineralization have been recognized, the first resulting in the deposition of the bulk of the quartz and some of the gold, the second in the deposition of the sulfides, the remainder of the gold and a small amount of quartz. There is no "barren zone", the values being found practically at the grass roots.

The ore occurs in fissure veins which cut the laminations of the Birch Creek schist country rock. Four principal veins have been discovered, one on the Helen S. claim and three on the Hiyu and Nars claims. The Helen S. vein has been traced (by underground workings and prospect pits) for a distance of 2000 feet from the level of Moose Creek across the Helen S. and Teddy R. clalms to the Hiyu, which is situated near the top of the ridge between Moose and Too Much Gold Creeks. It ranges in thickness from 6 to 15 inches, the average being approximately 9 inches. The general trend of the Helen S. vein is N. $65^{\circ}$ W., although local variations from this strike have been observed; it is practically perpendicular and intersects the veins on the Hiyu claim. The main vein on the Hiyu claim has been traced into the Nars claim, which is situated on the Too Much Gold Creek slope of the ridge, and was formerly owned by Nars, Anderson and Gibbs. It is from 10 to 12 inches thick and has a strike of N. $80^{\circ}$ W. with a vertical dip. At a point approximately 1000 feet from the east end line of the claim a smaller vein ranging from 4 to 6 inches in thickness, branches from the main Hiyu vein. It has a strike of $N .75^{\circ} \mathrm{W}$, and the dip is nearly vertical. A third vein has 
been discovered on the Hiyu claim having an east and west strike and a steep dip to the north. It should intersect the other Hiyu veins on the Nars claim. It is 14 to 16 inches thick, but the gold values it carries are lower than those in the other two Hiyu veins. On the Nars clafm the extension of the main Hiyu vein ranges from 6 inches to 2 feet in thickness although in a few places, due to mineralization of the wall rock, as much as 6 feet might be mined profitably.

The ore is not generally "frozen" to the walls, but gouge which might indicate subsequent movement along the direction of the vein is not common. Two intersecting faults have been observed, however, one on the Helen $S$. with a comparatively smal1 displacement to the north, and one on the Hiyu, with a displacement of 30 feet to the south.

In addition to numerous prospect pits the development work on the Hiyu group consists of three tunnels and a raise on the Heien S. claim, a turnel and a shaft on the Hiyu claim and a shaft on the Nars claim with two short drifts at the bottom. The main tunnel on the Heien 5. claim starts at a point about 50 feet above the level of Moose Creek and extends northwest along the strike of the vein for a distance of 1000 feet. At the 250-foot station a raise has been driven to the surface. A second tunnel at the level of the creek also extends along the vein for a distance of 500 feet. A third tunnei starting on the vein at a point approximately 175 feet above the main tunnel has been driven a distance of 40 feet. It will be extended through the Teddy R. claim and beneath the workings on the Hiyu claim. The tunnel on the Hiyu starts near the eastern end line of the claim at a point about 500 feet above the level of Moose Creek and extends westward along the main vein for a distance of 1300 feet. An additional 200 feet has been driven along the branch vein described above. A shaft, which is now used for ventilation but through which a considerable tonnage of ore was holsted during the prospecting stage of development, extends from the surface to the 800-foot station of the Hiyu tunnel. On the Nars claim the shaft is 100 feet deep and two drifts, one 50 feet and the other 60 feet in length, have been turned off at the 60-foot level Overhead stoping is employed. The stopes are just wide enough to permit work in them, the average being about 2 feet. Chutes are spaced 50 feet apart. Ore is delivered through them to 17-cubic-foot steel mine cars and tramed to the surface on an 18-inch, 8-pound 
track. The waste is sorted underground and used to fill the worked out stopes. On the Helen S. claim, with the exception of a floor five feet in thickness under the main tunne1, a) 1 of the ore between the creek level and main tunnels has been stoped for a distance of 400 feet from the portal, and between the main tunnel and the surface of the hill for a distance of 800 feet. On the Hiyu claim all of the ore between the tunnel and the surface has been removed for a distance of 1100 feet from the portal with the exception of a block 150 feet wide near the middle of the tunnel. A block 75 feet in width and extending to the surface was also taken from above the tunnel along the branch vein. The raise on the helen $S$ and the shaft on the Hiyu clafm are not protected by pillars but are cribbed carefully and the adjoining stopes have been filled with waste. No pillars are left in the stopes and it is expected to remove ultimately all the ore both in the Helen S, and the Hiyu claims. On the Nars claim approximately 200 tons of ore were removed by the former owners during prospecting. The present owners have not continued this work as they expect to mine the Nars clatm from the tunnel on the adjoining Hiyu clatm.

The property is equipped with a five-stamp amalgamating mill having a capacity of 15 tons In 24 hours. Ore is hauled with teams from the 50-ton bin at the portal of the Hiyu clajm and dumped into an underground chute above the main tunnel of the Helen S. claim. From here it is trammed in mine cars to the mill. After passing through a 7 by 9 inch Blake crusher, it falls into a 40 -ton bin from which it is fed by a challenge type feeder to the stamps. There are five of these in the battery, each weighing 1000 pounds and dropping 95 to 100 times per minute. The battery has a 50-mesh screen, through which the ground pulp passes to the amaigamating plate, which is 4 feet wide and 20 feet long and is provided with a mercury trap at the lower end. The tailings are being collected in a settling pond for possible future treatment, as they carry on the average approximately $\$ 4$ in gold. The mill is ordinarily operated for one 8-hour shift daily except during the winter months when it is idle.

Power for the mill is supplied by a 40 horse power 011 City boiler, burning wood fuel consisting, for the past three or four years, of stumps collected from the neighboring claims, the available supply of standing timber having been exhausted. The price of such 
fuel is variable, but on the average it is not far from $\$ 12$ for the equivalent of a cord. The boiler also supplies power for an Ingersoll-Rand air compressor which furnishes air for a Leyner drill sharpener, four Ingersoll-Rand stopers and five jackhammer drills. Work on this property has been continuous, except for temporary seasonal interruptions, since 1912. During that year prospecting, which was conducted by means of surface pits and trenches, revealed several veins ranging from 1 to 3 feet in thickness and carrying values of $\$ 50$ to $\$ 75$ at the surface. During 1913 the main tunnel on the Helen S. clatm was driven 450 feet and the raise at the 250 -foot station was driven to the surface. The creek level tunnel was also started. The following year the main tunnel was extended to 550 feet and the lower tunnel to 450 feet, both in ore throughout the entire distance. The stamp mill was moved to the property from Chatham creek and began crushing ore on September first. In 1915 the main tunnel was extended to 700 feet and a considerable body of ore between it and the lower level was mined and milled. In 1916 the Hiyu tunnel was started and the balance of the ore that has been taken from the Helen S. claim was mined and milled. Since 1916 work has been confined almost entirely to the Hiyu claim; and with one exception this is the only property in the Fairbanks district that has operated steadily throughout this entire period. As opportunity afforded, during that time the various interests in the Nars, Anderson and Gibbs claims were purchased, and it is the intention to extend the workings from the adjoining Hiyu claim into the Nars claim as soon as possible. Ohio Group

The Onto group which is owned by Thomas Gilmore and Gilbert B. Stevens, includes the Ohio, Mayflower, Early Bird and Grey Eagle claims, which are situated on the north side of Fairbanks Creek a short distance west of Too Much Gold Creek. The property is three miles from Meehan, the nearest postoffice, and 24 miles northeast of Fairbanks. The distance to Gilmore is 12 miles.

The principal development work on the Ohio Group consists of a crosscut tunnel which starts just below the wagon road near the lower end of the property and runs N. $30^{\circ}$ E. for a distance of 1000 feet and thence in an easterly direction for 150 feet to the foot of the "upper" shaft on the Ohio claim. At the 700-foot station a branch tunnel follows a small stringer for 50 feet in a northerly direction; near the 800-foot station there are two 
branches, one in a northerly direction 100 feet in length and one in an easterly direction 75 feet long; and at the 1000-foot station a fourth branch turns sharply to the west and connects with the 200-foot level of the main shaft on the adjoining Mizpah claim. The total length of the tunnel from this shaft to the portal is 1350 feet. Besides this tunnel several prospect shafts varying in depth from 30 to 80 feet have been sunk on the claims of the Ohio group and have encountered a variety of stringers and veins.

At the bottom of one of these shafts which is 25 feet deep there are two veins 15 feet apart, having a strike of approximately $\mathrm{N} .70^{\circ} \mathrm{W}$., with a dip of $45^{\circ} \mathrm{S}$, , but which at the surface are only 4 feet apart. The upper hanging wall of these veins shows strong slickensides and pronounced vertical streaks, indicating a fault plane along which the southern block has been relatively downthrown. The ore along the foot wall merges into the schist country rock. A second shaft which is 57 feet deep has exposed an eight-inch vein having an east-west strike with a dip of $45^{\circ} \mathrm{N}$. The ore in this vein, which is also free milling, is of low grade, perhaps $\$ 4$ or $\$ 5$ per ton. At the bottom of a third shaft, which is 70 feet deep, a drift was started in an easterly direction and then turned to the north. In this arift, which is 70 feet long, a quartz vein 4 to 6 inches thick was discovered carrying free milling gold with some pyrite and stibnite. The vein strikes east and west and dips $45^{\circ} \mathrm{N}$. The "upper" shaft on the Ohto claim exposed a body of low grade ore containing a large amount of sulphides. particularly galena and stibnite. And on the Early Bird claim a 25 foot shaft has uncovered a kidney shaped body of stibnite 12 to 15 inches thick.

The property is equipped with a five-stamp $\mathrm{m}^{111}$, which was installed in 1915 . The ore is dumped from the mine cars as they come out of the tunnel over a 1 1/2-inch grizzly. The oversize is crushed in a 7 by 9 inch Blake crusher and falls with the undersize from the grizzly to a small bin from which it is delivered to the stamps by a challenge feeder. The stamp battery contains five 1000-pound stamps which drop 95 times per minute and crush the ore through a 40-mesh slotted screen. The ground pulp passes over two $41 / 2$ by 8 -foot amaigamating plates arranged in series with a 1-inch step between them and having a slope of 2 inches per foot. The lower plate is equipped with a mercury trap from which tailings are discharged as waste with no attempt to save them. Power for the mil1 is derived from a 30-horse power, locomotive type, Erie boiler, which supplies steam for an 8 by 10-inch 
single cylinder engine, running at 180 r.p.m. The mill is housed in a neat, well constructed building.

Mizpah Mine

The Mizpah Mine, which is owned by Chas. L. Thompson of Fafrbanks and associates, is situated on the north side of Fairbanks Creek just west of the Ohio Group.

Two parallel veins 150 feet apart, having an east and west strike and a dip of $75^{\circ} \mathrm{S}$., have been discovered on the claim. The first or Mizpah vein ranges from 1 to $21 / 2$ feet in thickness. The ore is chiefly free-miliing gold-bearing quartz, but shoots of galena and lead carbinates carrying high values in silver occur at irregular intervals. An inclined shaft has been sunk on this vein to a depth of 220 feet at a point 250 feet fron the east end line of the claim and drifts along the vein in both directions have been driven at the 80, 160 and 220 foot levels. At the 80 -foot level in the drifts are each 100 feet in length; at the 160-and 220-foot leve1s the east drifts are 100 feet and the west drifts 175 feet in length. The east drift on the 220-foot level connects with the Ohfo tunnel. Approximately 1500 tons of ore, the average value of which is reported to have been $\$ 25$ per ton, have been stoped from these drifts and milled at the Ohto and other neighboring mitis. The second vein is 5 to 16 inches wide and carries approximately 20 percent stibnite with some free gold in a quartz gangue. A shaft has been sunk to a depth of 120 feet on this vein.

War Eagle Group

The War Eagle group is situated on the divide between the headwaters of Fairbanks and Wolf Creeks, and includes the War Eagle Leroy, Pioneer, Iron Mask, and Black Warrior claims, extending from west to east in the order named. They are four miles west of Meehan.

The bulk of the work for this group has been done on the Pioneer clatm, where several shafts and a number of prospect pits have exposed an antimony bearing vein 18 inches in thickness having a strike of N. $85^{\circ} \mathrm{E}$. and dipping $80^{\circ} \mathrm{N}$. together with three free milling gold quartz veins ranging in thickness from 6 inches to 14 inches. A sma 11 tonnage of ore has been shipped to various custom mills in the district from a part of which exceptionaliy high returns are reported. 
Cleary creek

Rexall Mine

The Rexall mine is situated near the head of Wolf creek, the easternmost branch of cleary creek. It is $21 / 2$ miles southeast of cleary postoffice and 6 miles from chatanika, the terminus of a 35-mile narrow gage branch of the Alaska Railroad.

The mine was opened by a tunne] running N. $25^{\circ}$ E. along the strike of a 3-foot quartz vein which dips $25^{\circ} \mathrm{NW}$. At a point 140 feet from the portal a smaller east-west vein dipping $60^{\circ} \mathrm{N}$. was intersected and since this carried higher values in gold. subsequent work was confined to its exploitation. It varied from 12 to 18 inches in width, the vein material being chiefly quartz and containing but a small amount of sulphides, A well defined and slickensided gouge seam occurred on the hanging wall. A shipment consisting of 25 tons of this ore was milled at Fairbanks from which an average recovery of $\$ 112$ per ton is reported. The development work on the vein consisted of 500 feet of drift, several raises and a winze. A mill was erected on the property, consisting of a Blake crusher, a Joshua Hendy 2-stamp mill and an amalgamating plate. The stamps weighed 1000 pounds each and were set for an 8-inch drop. The mill was run by an 0tto gasoline engine, which also pumped water for the mill from a well beneath the engine room. The mill was later sold to the owners of the David mine and moved to Skoogy Gulch.

Homestake Mine

The Homestake mine is situated on Wolf Creek a short distance above the Rexall.

Early prospecting revealed several promising veins on the surface and a tunnel was driven 750 feet in a southerly direction to intersect them. The first one of importance was encountered at a point 320 feet from the porta1. It has an east-west strike and dips $45^{\circ} \mathrm{S}$. It varies from 3 to 12 inches in width and in places carries high values in gold. The vein matter is chiefly quartz containing small amounts of antimony, copper and iron sulphides. Drifts were turned off to the east and west along its strike.

In the west drift a small pocket of high grade ore was found at a distance of 50 feet from the tunnel. In the east drift the first 90 feet from the tunnel were low in gold content, but the next 160 feet were driven through a good ore shoot about 12 feet high. The drift extended 50 feet beyond this through barren material to a point 300 feet from the 
tunnel where the vein was split up into several stringers. At a point in the east drift 135 feet from the tunnel an inclined raise driven 150 feet up the $45^{\circ}$ slope showed the vein to be continuous to the surface, although much of it was barren. A second rich shoot was found, however, 30 feet above the drift. It was 10 feet high and extended for more than 100 feet along a horlzontal pitch. The thickness of the vein averaged 9 inches in this shoot. A second raise in the east drift at a point 235 feet from the tunnel disclosed another shoot of high grade ore at a point 100 feet above the drift. The vein in this shoot averaged 5 inches in thickness and had a strike of N. $68^{\circ} \mathrm{E}$, and a dip of $40^{\circ} \mathrm{s}$.

The second vein was encountered 600 feet from the portal of the tunnel. It strikes $\mathrm{N}, 60^{\circ} \mathrm{W}$. and dips $45^{\circ} \mathrm{N}$. The vein matter is chiefly iron stained quartz in which visible particles of gold are occasionally found. Sulphides are not abundant, although stibnite, pyrite and chalcopyrite were observed. A drift was turned off for 100 feet along this vein In which it averaged one foot in thickness. At the face of the drift it pinched to a seam of gouge.

Pennsyivania Mine

The Pennsylvania mine is situated about a quarter of a mile southeast of the Rexall near the top of the divide between Wolf and Fairbanks Creeks. It lies but a short distance north of the War Eagle group.

The principal work at this mine consists of an inclined shaft 150 feet deep which was sunk on a vein about a foot thick. having a strike of $\mathrm{N} .76^{\circ} \mathrm{W}$, and a dip of $58^{\circ} \mathrm{S}$. Short drifts 25 to 30 feet long were run to the east and west at the 50 foot level from which a sma11 tonnage of selected ore was mined.

The property was equipped with a Little Giant mi17, having a capacity of 8 to 15 tons per day. From the mill the ground ore passed over amalgamating plates and hence through a launder to a Monarch table. The mill was situated on Fairbanks Creek about a half mile from the property. 
Chatham Mine

The Chatham mine is located at the head of Chatham Creek, which joins Cleary Creek about a mile above the mouth of Wolf creek. The mine is three miles from cleary postoffice and a half mile southwest of the Homestake mine.

The main vein, which ranges in width from 6 to 18 inches, has a strike of $N .60^{\circ} \mathrm{W}$. and dips $65^{\circ}$ to $80^{\circ} \mathrm{SW}$. After it had been traced for more than 500 feet by surface excavations, a crosscut tunnel was started in the side of the hil1 180 feet below the outcrop. The tunnel intersected the vein at a distance of 200 feet from the portal where drifts were turned off along the vein to the northwest and southeast for distances of 400 to 500 feet respectively. Raises were driven at 35 foot intervals from the drifts, several of them extending to the surface, and nearly all of the ore was stoped out for a dystance of 175 feet from the tunne 1 to the northwest and 225 feet to the southeast.

The vein material is chiefly quartz containing a small amount of arsenic, antimony and iron sulphides. Faults of small displacement are a cormon occurrence and some movement has also taken place along the strike of the vein. Although the value of the ore, which is reported to be $\$ 25$ to $\$ 40$ per ton, varies from place to place, the vein contains but few barren spots on the one hand or grade pockets on the other.

The main tunnel was extended to a distance of 1300 feet from the portal. At the $850-$ foot station a second vein carrying a large percentage of stibnite was encountered. It strikes $N \cdot 70^{\circ} \mathrm{E}$, and is practically vertical. A raise was driven 100 feet to the surface, and during 1916 a considerable tonnage of antimony ore was mined from it. What is probably a continuation of this stibnite vein cuts the main gold-bearing vein in the east drift at a point 150 feet from the tunne1.

The property is equipped with a 4-stamp mill consisting of two batteries of two $1000-$ pound stamps each, crushing the ore to 40 -mesh. The ground pulp passes over amalgamating plates equipped with mercury traps, the tailings going to waste. The mill is situated on Chatham Creek about a mile below the mine. 
Pioneer Mine

The Pioneer mine is located on the east side of Chatham creek about three quarters of a mile above the mouth.

The underground workings at this property, which was one of the first lode mining operations in the district, have long been inaccessible. They are reported to consist of an adit 125 feet long and a shaft about 100 feet deep with drifts to the east and west at the bottom from which 200 tons of ore were treated at the mill erected in 1912 .

It contained five 1000-pound stamps of the Joshua Hendy pattern, dropping 100 times per minute. The ground pump passed over two amalgamation plates, placed in series, and fitted with a mercury trap and auxiliary riffles. It was sold to Crites and Feldman and moved to the Hiyu group on Fairbanks Creek in 3914.

Free Gold Mine

The Free Gold mine, also known as the Rhoads-Hall property, is situated on the east side and near the mouth of Bedrock Creek, which flows into Cleary Creek a half mile west of Chatham creek. The mine is two miles southwest of Cleary Postoffice and 25 miles northeast of Fairbanks. The distance to Chatanika, the nearest railroad station, is six miles over a fairly good wagon road.

The ore deposit occurs in a series of fissure veins, consisting of a main vein which ranges from 1 to 3 feet in thickness with a small paralle1 stringer about 25 feet distant on each side. The gold is irregularly distributed through the vein material and in most cases uncombined with other minerals. In places it is more abundant near the walls of the vein and at others the vein is richest near the center. The sulphides of arsenic and antimony are often found associated with the gold in small amounts. The sulphides of zinc, lead, copper and iron are also occasionally present. The gold values appear to be higher wherever the quantity of sulphides is greater than usual. The vein material is grayish white opaque quartz, which is usualiy compact in texture.

The hanging and footwalls are Birch Creek schist and the vein cuts the lamination of the schist on a strike of N. $65^{\circ} \mathrm{W}$. to N. $75^{\circ} \mathrm{W}$. and at dips varying from $55^{\circ} \mathrm{S}$. to $63^{\circ} \mathrm{S}$. A number of instances of faulting have been observed and near the portal of the main tunne? the rock has been 50 thoroughly shattered and broken that the vein is almost unrecognizable 
for a distance of 200 feet. Two sets of faulting have been recognized, one across the vein with a high inclination, the other nearly parallel and practically flat. The displacement is usually small.

Here, as in the case of many other mines in the district, the gold has evidently been introduced at two distinct periods, although these may not have been separated by any appreciable geologic time. During the first period most of the quartz which forms the bulk of the vein and some of the gold were deposited. The second period resulted in the introduction of the sulphides, a small amount of quartz and the remainder of the gold.

Development work at the property includes a main tunne1, starting about 50 feet above the level of the creek, an intermediate adit known as the Penrose tunnel 150 feet higher, and an upper adit 50 feet above the Penrose. The main tunnel is 1300 feet long, the intermediate tunnel 280 feet and the upper adit 200 feet. At a point 800 feet from the portal of the main tunnel a winze follows down the vein for a distance of 112 feet. Drifts, aggregating 3200 feet in length, have been driven in both directions along the vein at the 70-foot level and at the bottom of the winze.

The property is equipped with a mill situated near the main tunnel in which the ore, after preliminary reduction in a jaw crusher, was fed to a stamp battery containing five 1000-pound stamps. These crushed the ore through a 40-mesh screen after which it passed over amalgamating plates. The tailings were treated on a canvas table where some of the slimed sulphides were removed as concentrates and shipped to a smelter. The mill has a capacity of 17 tons in 24 hours. The value of the ore fed to the mill while the property was being operated is unknown, but it is believed to have been $\$ 30$ or $\$ 40$ per ton. The loss in the tailings is reported to have been high.

The mine was discovered in 1908 and during the following year the vein was traced for 800 feet along the outcrop and the main tunnel ortven 90 feet. In 1910 the tunnel was extended to 630 feet. By the end of the following year 1200 feet of underground work had been completed and the mi1l erected and put in operation. During 1912 the main tunnel was extended to 975 feet, the intermediate and upper tunneis were started and the winze was sunk to a depth of 20 feet. By the end of 1913 the main tunnel had reached the 1280-foot 
station, the intermediate tunnel had been driven to 300 feet and the upper tunnel was 200 feet long. The winze was sunk to a depth of 112 feet and drifts aggregating 1000 feet in length were turned off at the 70 and 110 foot levels. The main and intermediate tunnels were connected by a raise and much of the ore between them removed. Approximately 3000 feet of development work were done during 1914 of which 2000 feet was on the 70 and 110 foot levels of the winze, and 1000 feet consisted of connections between the various levels. The mill operated 350 days during the year. An additional 200 feet ofunderground work was done the following year before operations were suspended on September 10, 1915, because of the increased operating expenses due largely to the high cost of fuel for pumping the water from the lower levels. They have not been resumed, although the mitl has been used since then for short runs by other parties. The total production of gold from this property is reported to have been approximately $\$ 600,000$.

Wyoming Group

The Wyoming group consists of nine claims, including the Alabama, California. Pauper's Dream, Texas and Wyoming, situated on the ridge between Bedrock and Chatham Creeks above the Free Gold Mine.

On the Wyoming claim an east-west vein 1 to 2 feet thick, consisting chiefly of quartz carrying free gold, has been opened by a tunnel 165 feet long and a winze 50 feet deep. The tunnel starts on the east side of Bedrock Creek about 1000 feet south of the Free Gold Mine. The winze starts near the middle of the tunnel and follows a $60^{\circ}$ dip which flattens to $50^{\circ}$ near the bottom. The vein has been traced into the neighboring Alabama clafm by a serfes of open cuts on the surface.

An east-west vein, having a dip of $60^{\circ} \mathrm{S}$. has been exposed on the California claim. It contains from 1 to 3 feet of free milling gold quartz. A shaft has been sunk on it for 60 feet, and near the bottom the dip of this vein also flattens.

A third vein which has a north-south strike and a steep dip to the west is exposed on the Texas claim north of the California. It has been traced across the latter claim into the Pauper's Dream on the south. The vein is from 2 to 4 feet wide and has a steep dip to the north. It differs from the other two veins on the property by carrying a rather large amount of sulphides consisting mainty of arsenopyrite. 
Tolovana Mine

The Tolovana Mine is situated near the mouth of Willow Creek, a tributary of Cleary creek lying about a half mile west of Bedrock Creek. The property is $21 / 2$ miles southwest of Cleary postoffice and 6 miles from Chatanika.

The main development consists of a tunnel that runs N. $75^{\circ} \mathrm{E}$. for 130 feet along a vein or shear zone composed of a number of small quartz stringers ranging from less than 1 inch up to 3 inches in thickness. From this point the tunnel follows a fault, which has offset the vein for 30 feet to the north, and then along the vein for 200 feet. An inclined shaft 100 feet deep has been sunk on the vein near the mouth of the tunne1, and a winze in the tunnel at a point 100 feet from the portal is also 100 feet deep. A drift connects the bottom of the shaft and the winze, and most of the ore between them has been mined and milled. A drift aiso extends east from the 50 foot level of the winze until it encounters the fault discovered in the main tunnel.

The ore in this lode is white, milky quartz interbanded with schist. The gold in it is free milling but appears to have some association with the small quantity of sulphides, chiefly stibnite, scattered through the quartz. The stringers are usually "frozen" to the schist, which on that account forms a considerable proportion of the ore going to the mitl.

About 100 feet south of the main tunnel a 50-foot shaft has exposed a vein of quartz ranging from ? 1/2 to 3 feet in width and having two well defined walls. Drifts were run 15 and 20 feet to the west and east, respectively, along the strike of the vein, which dips $50^{\circ}$ S. It carries a considerable amount of stibnite and free gold is visible both in the stibnite and in the quartz.

A shaft has also been sunk on an adjoining claim lying northeast of the Tolovana claim to a depth of 100 feet, from the 50-foot level of which drifts were turned off the the east and west along the vein for 50 and 30 feet, respectively. From the end of the west drift a raise was driven to the surface and the block of ore between the raise and the shaft was mined and milled. The vein contains quartz and stibnite, with smaller quantities of other sulphides.

The ore was originally treated in a Huntington mill, but this was replaced in 1912 by a 2-stamp Nissen mill. The stamps weigh 1300 pounds each and crush the ore through a 40-mesh 
screen. The pump then passes over the amalgamating plate after which the sulphides are removed from the tailings by an endless conveyor belt operated something after the principle of a Frue vanner. The capacity of the mi 11 is 6 to 8 tons per 24 hours.

Eldorado Mine

The Eldorado mine is situated on the headwaters of cleary creek about half a mile southwest of the Tolovana mine.

The development consists of 2 shafts and 3 drifts on a vein from 3 to 5 feet wide, striking N. $35^{\circ} \mathrm{E}$. and dipping $85^{\circ} \mathrm{N}$. The southwesterly shaft is 45 feet deep, 4 by 8 feet in size and is timbered and cribbed. From the bottom drffts have been driven along the veln in both directions, the one to the southwest being 30 feet and the one to the northeast 45 feet in length. They are timbered only where necessary and are 4 by 6 feet in size, Starting at a point 15 feet from the shaft along the south side of the northeast drfft, a stope has been mined which is 25 feet 1ong, 20 feet wide and 12 feet high. A body of silver bearing galena 2 to 3 feet in thickness was mined from this stope, and shipped to the smelter at Tacoma without concentration, but around the edges of the stope pyrite and zinc blende became predominant and further mining was discontinued. The ore body in the stope, before its removal, was found in practically a horizontal position, in contrast to the vertfcal position of the vein.

The northeasterly shaft, which is 4 feet by 6 feet in dimensions : has been sunk to a depth of 35 feet at a point 200 feet from the first shaft. It is also timbered to the full depth. From the bottom a drift extends for a distance of 45 feet southwest along the vein.

The ore contains a complex mixture of pyrite, galena zinc blende and stibnite in a gangue composed largely of quartz. The country rock in the vicinity is highly metamorphosed 7imestone. The different minerals composing the ore are intimately intermixed and, generally speaking, the size of the individual crystals is sma11. The ore carries silver in the proportion of 2 to $21 / 2$ ounces of silver per ton for every percent of lead. The most of the silver is contained in the galena but there is, in addition, no doubt a smali amount of silver mineral present - possibly a sulphide or antimonide. In the oxidized portion of the vein which extends to a depth of about 30 feet from the surface, the pyrite is changed to limonite and a part of the galena to carbonate; the zinc content is extremely low and the presence of silver chloride is suspected. 
Approximately four tons of this ore was tested at the Alaska Station of the Bureau of Mines in 1918, and a mi1l was designed for the treatment of the ore, the construction of which, however, was not recommended until a much larger tonnage of ore had been blocked out. The lessees were unable to do this at the time for financial reasons and the property has remained idle.

\section{Little Eldorado Creek}

Newsboy Mine

The News boy mine is situated at the head of Littie Eldorado Creek just over the divide from cleary creek. It is $71 / 2$ miles from Gilmore station on the Chatanika branch of the Alaska Railroad.

The vein trends N. $40^{\circ} \mathrm{E}$. with a dip of $73^{\circ} \mathrm{NW}$, and averages 2 or 3 feet in thickness. In places, however, the vein splits and encloses a horse of highly mineralized schist permitting the mining of 12 to 14 feet of ore. Fine grained quartz is the most abundant mineral but the vein carries a larger proportion of sulphides than most of the other mines in the district. The sulphides are chiefly pyrite and stibnite.

The mine has been developed an an incilned shaft 350 feet deep. Drifts aggregating more than 1500 feet in length have been turned off at the $60,115,150 ; 215$ and 315 foot levels and most of the ore between the upper levels has been stoped out for a distance of 75 to 100 feet from the shaft. Mining operations at this property were seriously hampered by an extremely complicated system of faults at which the best ore terminated abruptly, particularly that northeast of the shaft. In the absence of a knowledge of the exact relation and composite result of this faulting, several hundred feet of drifting failed to locate the vein again, and in 1915 the mine was closed down for lack of funds, in spite of a production of nearly $\$ 150,000$. (7200 $\circ i$ )

The ore was milled in a 5-stamp Hendy mill which was originally set up near the collar of the shaft but was later (1972) moved to a site on Cleary Creek opposite the mouth of Willow Creek where a more adequate supply of Water is available. The tailings from the amalgamating plates were treated on a No. 2 Deister concentrator in order to save the sulphides in the ore. 
Dome Creek

Soo Mine

The Soo mine is situated at the head of Dome Creek about four miles east of Ridgetop on the Chatanika branch of the Alaska Railroad. The property, which locally is sometimes called the Spaulding mine, includes among others the Wild Rose, Soo, Waterbury and Carnation claims which trend from west to east up the steep slope at the head of the creek.

The princtpal development work centers around an inclined shaft near the end line between the Wild Rose and Soo claims. It follows the vein, which has been named the wild Rose, to a depth of 100 feet and drifts 440 and 300 feet in length have been turned off to the east at the 50 and 100 foot levels, respectively. Most of the ore between these levels has been mined and milled. A second shaft was sunk on the same vein a short distance to the west from which some ore was also mined and milled.

The Wild Rose vein has an east-west trend and a steep dip to the north. The ore is chiefly quartz containing but a small amount of sulphides, which include stibnite and galena. Several faults of relatively small displacement were encountered in mining. The width of the vein is irregular, in some places being a mere seam of gouge, and at others widening to as much as seven feet.

A second vein, which a1so has an east-west trend and a steep dip to the north, has been named the Soo vein. At the west end line of the Soo claim the vein is 135 feet north of the Wild Rose, while at the east end line of the Soo claim the distance between the veins is only 60 feet. It has been prospected by a shaft 100 feet deep at the east end of the Soo claim and by a crosscut tunnel near the center of the claim.

The mine is equipped with a 2-stamp Joshua Hendy mill, situated on Dome creek half a mile from the mine. The ore was crushed at the mine before being hauled to the mill. The stamps weigh 1000 pounds each and crushed the ore through a 40 mesh screen. The tailings from the plates were discharged into a Pierce amalgamator which caught any quicksilver or rusty gold that passed over the plates. The capacity of the mill is reported to have been 10 tons in 24 hours. 


\section{Vault Creek}

Fredericks Mine

The Fredericks mine is situated on the ridge between Vault and Dome Creeks. The Chatanika branch of the Alaska Railroad crosses the property, although Ridgetop station lies about a mile to the north.

The property is developed by two shafts and a serles of open cuts. The western shaft is 300 feet deep and from it levels have been turned off along the vein in both directions at the 100,200 and 300 foot levels. These workings have exposed a fissure vein about three feet in width which strikes $N .70^{\circ} \mathrm{W}$. and dips $70^{\circ} \mathrm{N}$. at the surface but flattens to $45^{\circ}$ at the bottom of the shaft. The chief vein material is quartz containing some free goid

and, in places considerable masses of stibnite. The eastern shaft is 100 feet deep and in it the $80^{\circ}$ dip of the vein does not change in depth. The mineralization at this point has taken place in a fissured zone which has no well defined walls.

Pedro Creek

Rainbow Mine

The Rainbow mine is situated a short distance north of the junction of Skoogy Gulch with Twin Creek, which is one of the principal tributaries of Pedro Creek. The distance to Gilmore, the nearest point on the Chatanika branch of the Alaska Railroad, is five miles.

The ore occurs in a fissure vein having an east-west trend and a vertical dip. The vein averages from 10 to 12 inches in thickness and the vein material is glassy quartz containing rarely more than three per cent of sulphides. The chief sulphides are pyrite, arsenopyrite and stibnite, but galena and sphalerite have been identified. Visible gold is rare, although the ore is free milling. At the west end of the property the vein intersects a granite dike, which dips $N .45^{\circ} \mathrm{E}$. but in the ramainder of the property the walls of the vein are schist. The ore occurs in shoots which dip $45^{\circ} \mathrm{E}$. three of which were encountered in the 600 feet of the vein exposed on this and the adjoining property, the David.

The ore from the Rainbow mine has been taken out thru a shaft 330 feet deep which was sunk at a point 250 feet east of the end line of the claim. From the 100 foot level of the shaft drifts were run along the vein for 125 feet to the east and 250 feet to the west. Chutes were spaced at 35 foot intervals in the drifts. Approximately 1500 tons of ore, which 
is reported to have averaged $\$ 25$ per ton, were mined before the property became involved in litigation which lasted from 1914 to 1920 , during which the mine was idle.

David Mine

The David mine is located on Skoogy Gulch adjoining the Rainbow mine.

The vein, which is the western extension of the Rainbow vein, ranges from 8 to 10 inches in thickness and has an east-west trend with a vertfcal dip. The character of the ore is similiar to that found in the Rainbow mine.

The property was developed by an adit starting on the east sid of Skoogy Gulch about 20 feet above the creek level and running 300 feet east to the end line of the Rainbow claim. All of the ore between the tunnel and the surface has been mined and milled.

The mill contains a 7 by 9 inch Blake crusher, two 1000-pound Joshua Hendy stamps dropping 92 times per minute and crushing the ore through a 40-mesh screen, a silver plated amalgamating plate 4 by 18 feet, a Pierce amalgamator and a 6-foot Johnson vanner. Power for the mill is derived from a 40-horsepower Erie boiler, buring wood fuel. It also supplies the power for the Ingersoll-Rand air compressor which furnishes air for the drilis used in mining.

Anderson and Burch Mine

The Anderson and Burch property is situated three quarters of a mile above the mouth of Granite Creek, which flows into Pedro Creek just below the mouth of Twin Creek. It is 4 I/2 miles from Gilmore.

The principal feature at this property is a lode, ranging from 35 to 45 feet in thickness, composed chiefly of quartz with a small amount of pyrite, arsenopyrite and stibnite. The ledge was first discovered in a shaft 35 feet deep on the east side of the creek, and a cross-cut tunnel nearly 400 feet long was driven from a point just above the creek level to intersect the vein. An 80-foot cross cut, starting at a point 250 feet from the mouth of the tunnel, also cuts the lode which crosses the main tunnel at an angle of about $45^{\circ}$. $\mathrm{A}$ shipment of several tons of ore taken out when driving this crosscut was tested at the Citizens Test Mill in Fairbanks and an average of $\$ 5$ per ton in gold is reported to have been recovered. 
The tunnel intersects two other lodes, one about 18 feet thick at a distance of 50 feet from the portal, the other 57 feet thick at a distance of 185 feet. The first lode is a brecciated zone in the schist containing a number of small quartz stringers carrying pyrite and arsenopyrite. Although occasional rich specimens have been found, the ore as a whole is low grade. The second lode contains horses of schist between quartz vein matter interspersed with seams of blue-clay gouge. Arsenopyrite and pyrite are prominent constituents of the vein matter, which is low in gold content but contains some silver.

\section{Saint Patrick Creek}

Biliy Sunday Mine

The Billy Sunday mine, formerly known as the Leah or the Smith and McGlone property, is situated on the eastern flank of Ester Dome near the head of St. Patrick Creek. It is $11 / 2$ miles from Berry, the nearest postoffice, and 11 miles from Falrbanks. The distance to Happy, which is the nearest railroad station and the junction point between the Chatanika branch and the main line of the Alaska Raliroad, is $21 / 2$ miles.

The underground work includes two inclined shafts, one of them 195 feet and the other 100 feet deep, together with about 500 feet of drifts and levels. At the 60-foot level of the matn or deeper shaft one drift runs 100 feet northeast where it connects with the other shaft and another drift runs southwest for 120 feet. At the 120-foot level drifts run to the northeast and southwest for 60 and 125 feet, respectively. At the bottom of the shaft a drift runs 60 feet northeast and another 50 feet southwest. A 50-foot crosscut was driven In a southeasterly direction from the north drift on the 120 -foot level, and a winze sunk to a depth of 70 feet from the end of the crosscut. Most of the ore has been mined for a distance of 60 feet on both sides of the shaft between the 120-foot level and the surface.

The ore occurs in a fissure vein from 2 to 5 feet thick having a strike of N. $35^{\circ} E$., and a dip ranging from $70^{\circ} \mathrm{SE}$ to vertical. The vein material is mostly quartz containing a small amount (rarely more than three percent) of sulphides including pyrite, stibnite, some sphalerite and smaller amount of galena. The ore is free milling and visible gold can often be detected. The walls of the vein are schist. At a point about 30 feet below the collar of the main shaft the vein splits and encloses a horse of schist which is much shattered and filled with quartz stringers carrying some gold. At the 120-foot level a nearly 
horizontal fault has offset the vein about 50 feet to the southeast. The values in the vein appear to be original constituents and no indications of secondary enrichment have been observed in the 200 feet of depth thus far penetrated.

The ore is mined by the overhead stoping method, and falls into chutes spaced at 30-foot intervals along the drifts. It is skidded to the shaft and dumped into a 500-pound bucket which is hoisted along skids in the shaft by a 5-horsepower gasoline engine. At the collar of the shaft an automatic trip dumps the contents of the bucket into a mine car in which the ore is trammed on a short trestle and dumped into wagons for hauling to a nearby mi11. An Ingersoll-Rand jackhammer and a Sullivan stoper are used in drilling, for which air is supplied by an Ingersoll-Rand compressor driven by a 12-horsepower gasoline engine. The cost of gasoline at the mine is $721 / 2$ cents per galion.

The shafts are timbered and cribbed where necessary and tunnel sets are used in the drifts. A few stulls are also used in the stopes to hold the roof until the stopes can be filled with waste. The timber is local spruce logs ranging from 6 to 10 inches in diameter.

A smal1 amount of water was encountered at the 200-foot leve 1 which wi1? require a pump. The ore is hauled by wagons to a mill belonging to Thomas and Hess on the St. Paul claim, seven-eights of a mile distant, and dumped over a 2 inch grizzly, the oversize being broken by hand. From the grizzly the ore passes through a 7 by 9 inch crusher to a 60-ton bin from which it is delivered by a Challenge feeder to a 7-foot Lane mill. This crushes it through a 40-mesh screen, the ground pulp passing over an amalgamating plate 4 feet wide and 8 feet long. The tailings are allowed to go to waste. During a run of ore the mill ts usually operated for one 12-hour shift per day and has a capacity of one ton per hour. The feed to the mill has averaged $\$ 32$ per ton and the loss in the tailings amounts to about $\$ 4.50$.

The Billy Sunday is one of two mines in the district (the other being the Hiyu on Fairbanks (reek) that operated regularly during the years from 1918 to 1922 inclusive. Approximately 1600 tons of ore have been mined and milled from which $\$ 48,000$ have been recovered. The property is owned by George M., Joseph H. and Edward H. Smith, of Fairbanks. 
Ryan Lode Group

The Ryan Lode group contains eight ciaims, including the Ryan, Edna, Monte and Eva claims, situated about a quarter of a mile south of the Billy sunday mine, on the ridge between St. Patrick and Eva creeks, the latter being a tributary to Ester Creek.

The greater part of the work at this property has been done on the Ryan lode which has been traced by six shafts and a series of open cuts for more than 2000 feet along the side lines between the Ryan and Edna and between the Monte and Eva claims. The most extensive of these workings is a shaft 200 feet deep near the south end of the Ryan claim. At the 46-foot level it connects with the 100 foot station of an adit starting at the surface of the hill and extending 300 feet beyond the shaft and into the adjoining Monte claim. Three crosscuts, each about 50 feet long have been driven from the adft across the strike of the lode, and at the breast of the adit a winze has been sunk for 40 feet on the vein. At both the 100-foot and 200-foot ievels of the shaft crosscuts 100 feet long were driven across the lode.

On the Monte claim near the top of the hill a second shaft has been sunk to a depth of 50 feet and a crosscut has been driven at the bottom for a distance of 150 feet. Approximatel 300 feet southwest of this there is another shaft 40 feet deep. About 300 feet farther to the southwest, and on the Eva Creek slope of the hijl, there is a shaft 50 feet deep with a 50- foot crosscut at the bottom, and at an additional 300 feet in a southwesterly direction there is still another shaft 35 feet deep. On the Ryan claim several hundred feet to the northeast of the main workings and down the slope of the hill towards St. Patrick Creek, another shaft has been sunk to a depth of 100 feet with a 40 -foot crosscut at the bottom.

The ore in the Ryan lode occurs in a fractured or fissure zone ranging from 30 to 86 feet in width, and consists of a mixture of quartz and country rock containing a rather large amount (possibly as much as ten percent) of sulphides which are chiefly arsenopyrite and stibnite. The lode trends N. $30^{\circ} \mathrm{E}$. and has a steep dip to the east.

A second and nearly parallel lode, lying 400 feet to the northwest, has been traced for several hundred feet by a serfes of shallow shafts and pits. It averages six feet in thicknes During 1916 and 1917 this property was examined by a nationally known exploration company who spent some $\$ 35,000$ in prospecting the ore deposits in this vicinity. It is 
reported that their estimate of the available ore in the Ryan Lode group is 800,000 tons having an average value of $\$ 4$ per ton.

Bondholder Group

The Bondholder group includes the Bondholder, Bondholder Extension, Oakland, Oakland Extension and Yellow Jacket claims, situated at the head of the north fork of St. Patrick creek, about half a mile north of the Billy Sunday mine. This group is often referred to as the Tyndall and Finn property.

A ledge ranging in width from 6 to 12 feet, with a strike of $N .20^{\circ} \mathrm{E}$, and a dip of $40^{\circ} \mathrm{NW}$. , has been traced across the first four claims mentioned above, which are located along the trend of the vein in the order named. The vein matter is chiefly quartz and is frequently stained to a greenish color due to the oxidation of arsenopyrite. Other sulphides are of rare occurrence. The richest gold values are found near the hanging wall and particularly in the stained quartz.

The princlpal development work consists of a crosscut tunnel nearly 700 feet long starting on the Yellow Jacket claim (which adjoins the Bondholder on the northeast) at a point 250 feet vertically below the outcrop of the Bondholder ledge and driven to intersect that lode. In addition three shafts, two of which are nearly 150 feet deep, have been sunk on the ledge. At the 55-foot level of one of these a drift was driven for 50 feet to the southwest ajong the vein, which at this point has a minable thickness of twelve feet. Mohawk Group

The Mohawk group includes the Mohawk and Mohawk No. 2 claims situated just north of the Billy Sunday mine.

Two shafts on this property, each about 50 feet deep, have exposed a well defined ledge ranging from 2 to 8 feet in thickness. It is believed to be the extension of the Billy Sunday lode. The vein matter is quartz containing a small amount of stibnite and sphalerite. During the summer of 1922 approximately 300 tons of ore were mined from the Mohawk claim and treated at the neighboring St. Pau\} $\mathrm{m} 11 \mathrm{l}$, from which a recovery of more than $\$ 12,000$ is reported. 


\section{Last Chance Prospect}

The Last Chance prospect is situated on the ridge at the head of St. Patrick Creek between the Mohawk and Bondholder properties.

A 60-foot shaft which was sunk during 1922 exposed a quartz vein about two feet thick striking approximately N. $45^{\circ}$ E. and dipping steeply to the north. The vein material is chiefly quartz containing a small amount of arsenic and antimony sulphides. Visible gold can often be detected. Short drifts were turned off at the bottom of the shaft along the vein from which about 125 tons of ore were mined. The ore was treated in the St. Paul mill, nearby, and is reported to have yielded an average of $\$ 30$ per ton.

\section{Ester Creek}

Saint Paul Mine

The Saint Paul mine is located at the head of Eva Creek, the easternmost tributary of Ester Creek. The property is $17 / 2 \mathrm{miles}$ from Berry, the nearest postoffice, and $31 / 2 \mathrm{mlles}$ from Happy junction on the Alaska Railroad.

The main opening of the Hudson mine is a 200-foot shaft from which a large amount of drifting has been done, chiefly at the 100-foot level. At this depth a 20-foot crosscut to the west intersected a fissured zone, 15 feet wide, filled with stringers and lenzes of quartz between mineralized schist. It strikes N. $20^{\circ} \mathrm{E}$, and dips $45^{\circ} \mathrm{NW}$. It has been followed by a drift for 160 feet northeast along the strike until it was abruptly terminated by a transverse fault dipping $60^{\circ} \mathrm{SW}$. Some very rich ore has been mined and milled from shoots in the stringers of this lead.

At the end of the west crosscut a drift was also run for 200 feet to the south along the strike of a 4-inch quartz stringer. Several short crosscuts have been driven to the east and west from this drift, disclosing other small stringers more or less paralle 1 to the drift.

A crosscut was also driven for a distance of 100 feet east from the shaft.

The property is equipped with a mill containing two Nissen stamps. It is situated on Ester Creek a little more than half a mile from the mine. 


\section{ANTIMONY MINES}

During the years 1915 and 1916 a number of antimony mines in the Fairbanks district were opened to take advantage of the high price of that metal caused by the exceptional demand for it in connection with the maufacture of war munitions, and nearly 4000 tons of the ore were shipped to the various purchasers throughout the United States. The most important of these mines were situated on Vault and Little Eldorado Creeks, which are tributaries of Chatanika River; on Chatham Creek, a tributary of Cleary Creek; and on Eva Creek, a tributary of Ester creek. In 1917, however, the price of antimony declined to a point which no longer furnished a profit after paying mining costs and transportation charges, and hence the antimony mines in this district have since been idle.

\section{Vault Creek}

Black Eagle Mine

The Black Eagle mine was the largest producer of antimony ore. It was situated on a small branch of Treasure Creek which is the west fork of Vault Creek. The property is $41 / 2$ miles from the Vault Creek summit on the Chatanika branch of the Alaska Railroad.

The ore occurred in a shear zone ranging from 3 to 10 feet in thickness and having an east-west strike and a dip of $50^{\circ}$ to $70^{\circ} \mathrm{S}$. The enclosing country rock is schist. The richer portions of the ore were found in shoots or lenses varying from a few feet to 40 or 50 feet in length. A small amount of free gold and some silver accompanied the antimony.

The deposit was mined from an adit following along the strike of the lode. Hand drflling was used and the ore was sorted at the mine before shipment. It was hoisted from the mouth of the adit to the top of the ridge on the south side of Treasure Creek by an inclined tran 3000 feet long. From this polnt a wagon road follows the tip of the divide to the railroad. The mine produced approximately 2500 tons of ore during the two years of its operation.

Gijmer Mine

The Gilmer mine is situated on the east side of Vault Creek, about a quarter of a mile south of the Fredericks mine which has aiready been described.

The antimony ore at the Gilmer mine occurred as lenses or shoots in a fractured zone ranging from 1 to 5 feet in thickness and striking $N$. $70^{\circ}$ E. with a dip of $60^{\circ}$ NW. The 
property was developed by an inclined shaft about 100 feet deep with drifts and stopes on either side from which several hundred tons of high grade antimony ore were mined.

\section{Little Eidorado Creek}

Hindenburg Mine

The Hindenburg mine is situated on the west side of Little Eldorado Creek about two mi Tes above the Chatanika branch of the Alaska Ratlroad.

The workings consisted of a shaft about 25 feet deep from which drifts extended along an ore body trending northeast and southwest and dipping $60^{\circ} \mathrm{SE}$. Approximately 200 tons of antimony ore were shipped from this property in 1916.

\section{Chatharl Creek}

Chatham Mine

The Chatham mine is essentially a gold mine and has already been described as such, but in 1916 several tons of antimony ore were mined from a stope 60 feet above the main tunne] at a point 850 feet from the portal. The stibnite occurred in a small vertical vein about 18 inches thick which strikes N. $70^{\circ} \mathrm{E}$. It cuts the main vein in the east drift at a point about 150 feet from the tunnel.

\section{Eva Creek}

Stibnite Lode

The Stibnite lode is situated at the head of Eva Creek about two miles north of Berry postoffice and seven miles from Ester station on the Alaska Railroad.

The ore occurred as lenses or kidneys of stibnite in a shear zone in the schist country rock. The lode ranged from 1 to 3 feet in thickness and had a strike of N. $30^{\circ} \mathrm{W}$. with a steep dip to the north. The gangue mineral was chiefly quartz which was usually stained by alteration products of the stibnite. The mine produced about 100 tons of antimony ore during 1915 and 1976.

\section{TUNGSTEN MINES}

There was also considerable prospecting and mining of tungsten ore s during 1915 and 1917 likewise engendered by the high price of that metal due to abnormal war conditions. The work centered in two districts, one near the head of Gilmore Creek and the other near the head of First Chance Creek, both of which are tributaries of Goldstream from the south. 
Columbia Group

The columbia group consists of three claims situated at the head of Steele creek just over the divide from First Chance Creek and half a mile south of the Tanana group.

The principal development work consists of an adit driven for 80 feet along the granite hanging wall of a vein which strikes N. $20^{\circ} \mathrm{W}$. and dips to the northeast. The vein, which is three feet thick, consists of decayed stringers of country rock impregnated with a small amount of scheelite. A Faust concentrating mill was erected at the property in 1917. Other Properties

Scheelite has been found at a number of other properties in the vicinity, including the Tungsten Hill Group of eight claims lying a quarter of a mile west of the Tanana Group, the Spruce Hen Group of three claims a quarter of a mile east of the Tanana group, and the Blossom Group west of the Tungsten Hill.

Work on these properties has been confined to surface trenching and, although in several instances encouraging prospects were found, no appreciable development work was done prior to the drop in the price of tungsten ore which effectively terminated tungsten minting in the Fairbanks district.

\section{FUTURE OF GOLD LODE MINING}

It is true that the inactivity from 1977 to 1921 has created in some quarters a feeling of skepticism as to the future of lode mining in the Fairbanks district; but even a brief survey of the three reasons for that inactivity, namely, lack of adequate transportation. facilities, shortage of fuel, and the high cost of supplies, if made in the light of conditions as they now exist will show that such skepticism is without foundation in fact.

The lack of adequate transportation facilities was caused by the fact that shipments of supplies to Fairbanks could only be made on river steamers with a long haul up the Yukon River from St. Michael or a longer haul downstream from Whitehorse after a costly rafiroad portage from Skagway, and by the fact that such steamers could operate but four or possibly five months at best during the summer of each year. Hence, not only were freight charges high but, what is more important, shipments had to be planned at least a year in advance and a much larger stock of supplies had to be carried. This condition has been entirely changed by the completion of the Alaska Railroad, which now operates bi-weekly trains from 
Fajrbanks to open tidewater at Seward throughout all the twelve months of the year. The shortage of fuel was due to the exhaustion of the available standing timber on most of the important creeks in the district, necessitating longer hauls and a consequentiy higher price. This has been remedied by the bullding of a spur from the railroad at Healy to the coal mines at Suntrana, as a result of which fuel for mining operations, the cost of which is one of the big items of expense, is now available at any point on the main line or the Chatanika branch at a much lower cost per horsepower than has ever prevailed during the last 30 or 15 years. And the cost of supplies, although it has not as yet reached the pre-war level is appreciably lower than it was five years ago and is steadfly decreasing each year. In the above descriptions of gold mines and prospects the attempt has been made to include none but those which have either made an appreciable production or show reasonable possibilities of such. There are no large and rich bonanzas in the list, however, and future mining at most of them must be done slowly, carefully and economically by, or at least under the direct personal supervision of, the owners or operators. The outstanding factors in the success of the two mines in the district that were able to operate during the lean years are this direct personal supervision, the elimination of overhead expense, and the postponement of mill construction until fully warranted by the mine development. On the other hand the above list contains several instances where the showing was as good if not better than these two mines but where financial failure was caused by a disproportionately large organization with high overhead expense, or by the investment in a mill or an expensive crosscut tunnel in advance of adequate delimitation of the ore body. If this past experience is used as a guide to avoid similar errors in the future there is no hesitancy in predicting a steady and sound increase in gold mining activity in the Fairbanks district. 